\title{
PATRICK CHAMOISEAU E A RELEITURA DO IMAGINÁRIO EM PAÍS DOMINADO
}

\author{
Luciana Ambrósio
}

\begin{abstract}
RESUMO
Este texto apresenta o primeiro capítulo da obra Écrire en Pays Dominé, de Patrick Chamoiseau, a fim de reconhecer a existência de uma dominaçáo que atua silenciosamente sobre o imaginário coletivo martinicano e de investigar o papel da (re)leitura de obras literárias como ferramenta de resistência a esse controle.
\end{abstract}

PALAVRAS-CHAVE: dominação, escrita, leitura.

\section{Inquietações}

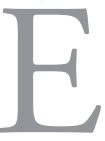

instigante pensarmos como a literatura é produzida dentro de um espaço de dominação. Será ela uma forma de resistência, de combate a esse domínio? Algo que nos faça "ler levantando a cabeça"? Ou será meramente uma expressão artística subordinada a algum tipo de poder? Como entender mais de três séculos de produção literária martinicana sem levar em consideração os mais de três séculos de escravização humana, criativa e intelectual? A literatura responde à História, e no caso da Martinica, respondeu refletindo um imaginário estagnado e completamente dependente do imaginário francês. E por quê? - perguntaria o leitor. Porque essa região foi palco de uma das formas mais perniciosas de colonização, que é, segundo o pensador, romancista e poeta martinicano Edouard Glissant, a de se assimilar uma comunidade ${ }^{2}$.

1 BARTHES, Roland. O Rumor da Lingua. Trad. de Mario Laranjeira. São Paulo: Martins Fontes, 2004. p. 26.

2 GLISSANT, Édouard. Le Discours Antillais. Paris: Gallimard, 1997. p. 21. 
Formada sob o jugo da violência colonial, a América da crioulização ${ }^{3}$ vive a experiência de recompor, através de vestígios da memória, uma sociedade mestiça e inédita. Durante os quase três séculos de tráfico negreiro, os milhôes de africanos transplantados para o trabalho escravo nas ilhas do Caribe desembarcam desprovidos dos artefatos de sua cultura original, de sua língua, de seus deuses, de seus objetos usuais, de seus costumes e de suas ferramentas, fato que leva Glissant a denominá-los migrants nus ${ }^{4}$. Nesse contexto plural, não há como se estabelecer uma relação de continuidade com o passado, pois a memória aí se apresenta de forma fragmentada e por isso recomposta através de vestígios, de fragmentos da tradição.

$\mathrm{Na}$ plantação, essas diversidades humanas deverão aprender a renascerem juntas, a viverem juntas, a entrarem em acordo, a partilharem em condiçôes desarmônicas, violentas e arriscadas. Ninguém veio para fundar uma civilização ou uma cultura. Estavam lá para enriquecerem, para serem exploradas ou para explorarem a si mesmas, para dominarem ou tentarem resistir a uma morte programada. Esta dinâmica de opressão e de resistência, de ferimentos e de submissão, de proibição e de licenciosidade, no contexto particular do Novo Mundo, vai ativar esta alquimia antropológica que é a crioulização5

No caso do Caribe crioulo-francófono, a colonização escravocrata na região, iniciada no século XVII sob o comando da Coroa francesa, possibilitou o entrechoque étnico e cultural de africanos, brancos, índios caraíbas e arawakes e, mais tarde, com a imigração ocorrida após a abolição da escravidão em 1848, de indianos, chineses e sírio-libaneses. Nesse turbilhão de raças, homens, línguas e concepçóes de mundo, nasce a cultura crioula, de natureza incerta e plural.

3 Compreende o Caribe, o nordeste do Brasil, as Guianas Inglesa e Francesa e Curaçao, o sul dos Estados Unidos, a costa caribenha da Venezuela e da Colômbia e ainda uma grande parte da América Central e do México. É também denominada Néo-Amérique. Cf. GLISSANT, E. Introduction à une Poétique du Divers. Paris: Gallimard, 1996.

Decidimos traduzir para o português todas as citaçóes apresentadas neste artigo.

4 Idem, Ibidem, p.14.

5 CHAMOISEAU, Patrick. "Dans la Pierre-Monde". Potomitan, http://www.potomitan. info/divers/pierre.php, 13/12/2010. Grifos do autor. 
A busca por uma identidade implica a busca por uma origem. Essa necessidade identitária é satisfeita através de um mito fundador, um ponto de referência primordial que nos ajuda a definir uma rede de relaçóes com o mundo. Toda e qualquer narrativa sobre a Gênese em uma sociedade atávica parte do princípio de uma filiação e consequente legitimidade sobre um território; por extensão, nossa consciência histórica, em termos ocidentais, vem de uma série de mitos de elucidação sucedidos por contos e relatos, romances e poemas, e sobretudo pela História que permeia toda essa literatura.

Sendo a História filha do mito fundador, Glissant questiona: "o que será a consciência histórica, senão o sentimento generalizado de uma missão a cumprir, de uma filiação a manter, de uma legitimidade a preservar, de um território a expandir?" 6 . Trata-se de uma noção de identidade que se configura sob a forma de uma raiz única, aquela que, por um lado, exclui o diferente em defesa da preservação da tradição; mas que, por outro, tenta integrá-lo ao seu modo de pensar a fim de perpetuar uma certa visão de mundo e assim expandir os limites de seu território. É por essa perspectiva do universalismo ocidental que o colonialismo francês nas Antilhas promoveu uma política de assimilação cultural e de discriminação racial ao forjar, na então população que se formava uma mentalidade baseada nos valores ocidentais, desvinculada, portanto, de sua história verdadeira.

Diante desse panorama, vale se perguntar: Como escapar às amarras de um passado traumático e moldado historicamente segundo a visão ocidental? Ou como já havia se perguntado o escritor martinicano Patrick Chamoiseau em 1997, em sua obra Écrire en Pays Dominé: "Como escrever quando seu imaginário se alimenta, desde a manhã até os sonhos, com imagens, pensamentos, valores que não são os seus? Como escrever quando o que você é vegeta além dos elos que determinam sua vida? Como escrever, dominado?"8

Neste artigo, propomo-nos analisar o primeiro capítulo dessa obra a fim de mostrar como se realiza o domínio do imaginário e, a partir daí, discutir a importância da (re)leitura literária como procedimento de libertação.

\footnotetext{
6 Idem, Introduction à une Poétique du Divers. Paris: Gallimard, 1996. p. 63

7 CHAMOISEAU, Patrick. Écrire en Pays Dominé. Paris: Gallimard, 1997.

8 Idem, Ibidem, p. 17.
} 


\section{Dominação silenciosa}

Écrire en Pays Dominê nos fornece de antemão, logo no seu título, elementos que podem guiar nossa leitura. $\mathrm{O}$ uso do infinitivo verbal Écrire leva a crer na possibilidade de uma expressão artística; o termo Pays designa um território demarcado por fronteiras no qual habita uma coletividade cujos membros são ligados por laços histórico-culturais e linguísticos; por fim, o adjetivo Dominé como caracterização dessa regiáo abre para pensarmos em algo que não vai bem, que está aprisionado ou de certo modo esmagado, não liberto. Em termos gerais, uma identidade que se quer livre do domínio através do uso da escrita. Teríamos aqui a chave de leitura?

Essa obra apresenta-se repleta de elementos autobiográficos, informaçôes de cunho histórico e um vasto repertório imaginativo, por isso a dificuldade em afirmar a qual gênero pertence. Narrativa em prosa, com alto grau de poeticidade, é um misto de vários procedimentos literários que ora a colocam como um romance autobiográfico por mostrar o percurso pessoal do autor como escritor e leitor, ora como um ensaio crítico-literário por dar conta também da relação da literatura com a situação social, política e cultural da Martinica.

Mestre em fragmentar-se em diversas personae dentro do espaço narrativo, Patrick Chamoiseau entra em cena, em Écrire en Pays Dominé, vestindo a máscara de um escritor angustiado e se apresentando com seu próprio nome. Disposto a entender de que forma age a dominação sobre o seu fazer-literário, Chamoiseau desabafa:

Eu precisava então interrogar minha escrita, percorrer suas dinâmicas, suspeitar das condições de sua eclosão e revelar a influência que exerce sobre ela a dominação que-não-mais-se-vê. Mas como? [...] Essas questóes atormentavam minha escrita. Elas perturbavam o romance em curso, inquietavam meus projetos, paralisavam meus sonhos ${ }^{10}$.

\footnotetext{
9 Idem, Ibidem.

10 Id.,ibid., p. 22.
} 
É a partir deste trecho, em que o escritor mostra-se atormentado e cheio de questôes, que surge um segundo personagem: "Elas suscitaram um estranho personagem, uma espécie de velho guerreiro, vindo de todas as épocas, de todas as guerras, de todas as resistências, de todos os sonhos que puderam nutrir os povos dominados" 11 . O velho guerreiro acompanha o escritor ao longo de toda a narrativa, compartilhando sua experiência diante dos três tipos de dominação exercidos sobre a Martinica - a Brutal, a Silenciosa e a Furtiva - e rememorando fatos históricos e histórias esquecidas ou forçosamente recalcadas pela população. Contida em um metatexto denominado Inventaire d'une Mélancolie, sua fala, fragmentada e apresentada em caracteres tipográficos menores, pretende complementar a narração do escritor como uma mise en abîme, de modo a fundamentar a existência de um controle e legitimar a angústia de Chamoiseau. Operando como um espelho frente as suas palavras, o velho guerreiro fornece razóes que justificam o mal-estar do escritor em função da história martinicana, de forma a traçar como a dominação age no imaginário e pelo imaginário. Para tanto, sua narração se desenrola a partir da chegada dos colonizadores franceses na Martinica em 1642 até culminar no tempo presente da enunciação.

O velho guerreiro me deixa ouvir: ...eu me lembro, eu te disse. Mas já que estás pronto a este pensamento quilombola, eu te falarei de três dominaçôes: a Brutal, a Silenciosa e a Furtiva... (ele ri)... Maldito sonhador, eu vou insistir nisso sem parar, como o mais enfadonho dos repetidores!... - Inventário de uma melancolia ${ }^{12}$.

Somos levados a crer, segundo a voz murmurada do personagem, que a "Dominação Silenciosa", que se realiza no e pelo imaginário, opera sobre o inconsciente coletivo martinicano a partir do momento em que a ilha passa a ser palco, de meados do século XVII até o final do XIX, de um sistema negro-escravocrata de plantação de cana-de-açúcar financiado pela França. Muito rapidamente, os índios Caraíbas são quase totalmente exterminados

\footnotetext{
11 Idem, Ibidem.

12 Idem, Ibidem, p. 23. Grifos do autor.
} 
pelos brancos recém-chegados à ilha e substituídos pela mão de obra africana a partir de 1685, ano que historicamente marca o início do período da habitation $^{13}$ e da publicação do Code Noir ${ }^{14}$, documento que regulamentava a vida dos escravos.

Diante da usurpação mental e física por que passa a população de africanos já no momento da travessia rumo às Antilhas, quando escrava, seu imaginário começa a ser moldado segundo uma representação simbólica elaborada pela metrópole francesa e que tem por efeito domesticar e inferiorizar por autodepreciação toda a população escrava. O psicanalista martinicano Frantz Fanon, em Peau Noire, Masques Blancs ${ }^{15}$, analisa como o complexo de inferioridade do negro está ligado a fatores econômicos e também à "epidermização" dessa inferioridade. Assim, o que se chamaria de "alma negra" seria, para ele, uma construção do Branco.

Todo povo colonizado - ou seja, todo povo no seio do qual nasceu um complexo de inferioridade, em função da morte da originalidade cultural local - se situa diante da linguagem da nação civilizadora, ou seja, da cultura metropolitana. Quanto mais o colonizado adotar os valores culturais da metrópole, melhor se livrará de sua selva. Quanto mais ele rejeitar sua negrura e sua selva, mais branco ele se tornará ${ }^{16}$.

Embora Fanon faça um estudo desse fenômeno no século XX, percebemos que sua origem remonta ao período da habitation, tornando claro que o domínio sobre o inconsciente coletivo do negro perdura há mais de três séculos, visto que a lógica estabelecida no imaginário da população negra sempre

13 O termo francês habitation é empregado no contexto da colonização francesa na América e no oceano Índico para designar um lugar de residência permanente com exploraçáo agrícola. A habitation açucareira escravagista é uma unidade autônoma de produção de cana-de-açúcar e em torno da qual será estruturada a sociedade crioula. No final do século XIX, o termo é substituído pela palavra inglesa plantation. Cf. BELROSE, Vincent H. La société d'habitation: une civilisation historique. Kapes Kreyol, http://kapeskreyol.potomitan.info/dissertation4.php, 21/11/2011.

14 http://www.assemblee-nationale.fr/histoire/esclavage/code-noir.pdf, 10/03/2012.

15 FANON, Frantz. Peau Noire Masques Blancs. Paris: Éditions du Seuil, 1952.

16 Idem, Ibidem, p. 14. 
foi a de apagar traços não brancos que pudessem lembrar a "selvageria" africana, a miséria indiana ou a podridão do sistema escravocrata, tudo isso em benefício da ascensão social e cultural nos moldes metropolitanos franceses, nos moldes de uma cultura "que transformava todo semibicho em homem"17.

Com a decadência do sistema em razão da crise do açúcar no mercado internacional e a abolição da escravidão em 1848, iniciou-se um período marcado por um só desejo: tornar-se francês. Negros, mulatos e békés ${ }^{18}$ são confrontados pela necessidade de ascender à cultura francesa para escapar à estagnação das plantaçóes de cana e dos vários trabalhos informais que passam a surgir nos burgos e nas pequenas cidades. Enquanto diversas colônias da África negra e do Magrebe travavam lutas de descolonização, a Martinica foi anexada à França como departamento ultramarino em $1946^{19}$, período cuja dominação do imaginário pelo imaginário começa a se tornar cada vez mais fortalecida pela política assimilacionista francesa.

Ora, diante de todo o fascínio exercido pelo centro francês com suas políticas assistencialistas e de subvenção, a metrópole colonial transforma-se em "Mãe-Pátria”, operando uma espécie de fusão mental ${ }^{20}$. O martinicano, então, passa a ver o mundo através do filtro do olhar francês, o que provoca uma aquisição quase total de uma identidade que não condiz com seu real ${ }^{21}$. Podemos ilustrar esse panorama através da ironia presente em um trecho de Écrire en Pays Dominé: "Diante de você, as costas curvadas frente aos transatlânticos, às agências operacionais e aos montes de hotéis que civilizam as praias e ao turismo-rei que santifica os lugares"22. A comparação da geografia das Pequenas Antilhas - "as costas curvadas" - com a submissão aos valores europeus já havia aparecido nas palavras do poeta martinicano Aimé Césai-

17 CHAMOISEAU, Patrick \& CONFIANT, Raphaël. Lettres Créoles. Paris: Gallimard, 1999. p. 118.

18 Nas Antilhas Francesas, o termo béké é usado para caracterizar os descendentes dos primeiros colonizadores brancos europeus.

19 Pela lei de 1946, a Martinica, a Guadalupe e a Guiana Francesa são anexadas à França após um longo processo histórico e tornam-se departamentos ultramarinos; consequentemente, a populaçáo passa a gozar dos mesmos direitos e deveres de um cidadão francês.

20 CHAMOISEAU, Patrick. Écrire en Pays Dominé, op. cit., p. 48. Grifos do autor.

21 BERNABÉ, Jean, CHAMOISEAU, Patrick \& CONFIANT, Rafaël. Éloge de la Créolité-In Praise of Creoleness. Paris: Gallimard, 1993.

22 CHAMOISEAU, Patrick. Écrire en Pays Dominé. op. cit., p. 19. 
re: "o arquipélago arqueado como o desejo inquieto de se negar"23.

Vimos brevemente como se processa o controle do imaginário pelo imaginário, tomando como fonte as palavras do velho guerreiro e partindo de dados históricos para traçar como se constituiu o inconsciente coletivo martinicano. Voltemos ao escritor a fim de entendermos como o domínio intelectual e ideológico molda o imaginário criativo e como isso se reflete na expressão artística martinicana.

\section{Memória de leituras}

É através do diálogo instaurado com este personagem “jamais claro, hostil em suas certezas, mas vivaz em crenças" ${ }^{24}$, que o escritor inicia uma viagem em si mesmo, um passeio em companhia de seus autores preferidos e de livros adormecidos que, segundo ele, embora caídos em uma espécie de esquecimento, aguardam serem novamente tocados, folheados, marcados, como se em estado de vigília, estivessem prontos para uma nova leitura.

Quando o livro adormecido é um grande livro, seu sono tem o charme de uma promessa. O grande livro adormecido atrai, nós o pegamos e o guardamos sem saber muito por quê. É uma presença no mundo fechado sobre uma resposta. Esta resposta aguarda se abrir à curiosidade de uma leitura ou do que precede toda leitura. O livro adormecido não vai modificar o mundo, mas sim o seu leitor; sua abertura ao mundo, por intermédio de seu leitor, fará a alquimia sempre recomeçada, proteiforme de sua resposta. Terá tantas respostas quanto leitores, sem jamais falhar a si mesmo ${ }^{25}$.

É como se Chamoiseau, nesse trecho, quisesse transmitir ao leitor a imagem de si próprio como leitor, como se o ato de ler fosse ainda uma atividade mais intelectual do que o de escrever. A leitura participaria, assim, da própria

23 CÉSAIRE, Aimé. Cahier d'un Retour au Pays Natal. Paris: Présence Africaine, 1983. p. 24.

24 CHAMOISEAU, Patrick. Écrire en Pays Dominé, op. cit., p. 23.

25 Idem, Ibidem, p. 29-30. 
criação, uma vez que o personagem do escritor, estando consciente da existência de uma dominação que não se vê, leva a cabo seu desejo de compreender de que modo age a dominação sobre sua escrita e realiza, entâo, uma releitura memorial de sua experiência literária desde a infância até a idade adulta. "Tantas leituras desde a infância me deixaram mais que lembranças: sentimentos. Mais que uma biblioteca: uma sentimenteca" 26 .

Revisita, precisamente, obras produzidas dentro e sobre o espaço martinicano, traçando, dessa maneira, assim como fez dois anos mais tarde em Lettres Créoles ${ }^{27}$, os caminhos da literatura antilhana. Além de nos fornecer traços sobre o que foi produzido e consumido em termos de obras literárias na Martinica, o personagem, ao sondar sua sentimenthèque, recupera e evidencia - dentro da própria estrutura narrativa e ao longo de todo o romance - grandes clássicos da literatura. $\mathrm{O}$ uso do neologismo sentimenthèque em lugar da palavra "biblioteca" mostra que os trechos apresentados não são ipsis litteris transcritos da obra a qual pertencem e sim, oferecidos sob a forma de fragmentos de memória, do que restou como sentimento da leitura: "De Pessoa: Não acredite na mentira do eu: espalhe-a em lotes de verdades, em outros tantos de relaçóes criadoras, é plenitude de uma corrida a seus próprios tesouros. - Sentimenteca" 28 .

Escolarizado em uma época em que a língua francesa reinava absoluta sobre a construção do imaginário e a prática da língua crioula se limitava ao espaço doméstico e familiar, Chamoiseau torna-se um forte conhecedor da literatura clássica franco-ocidental e a paixão pelos livros o leva a escrever ainda criança suas próprias histórias. Suas primeiras experiências com a escrita, fosse desenhando, rabiscando ou escrevendo, reproduziam o que lhe era fornecido pela leitura desenfreada de romances policiais, clássicos literários, fotonovelas e histórias em quadrinhos. Para ele, "naquele tempo, cada leitura era boa, todas as leituras se equivaliam" 29 .

Quando adolescente, Chamoiseau percebeu a pulsão mimética a que estava condicionado o ato da escrita e isso se refletia nos locais e personagens de

26 Idem, Ibidem, p. 24. Grifos do autor.

27 CHAMOISEAU, Patrick \& CONFIANT, Raphaël. Lettres Créoles. Paris: Gallimard, 1999.

28 CHAMOISEAU, Patrick. Écrire en Pays Dominé, op. cit., p. 190. Grifos do autor.

29 Idem, Ibidem, p. 41. 
suas histórias que nada se assemelhavam aos locais e personagens da cultura crioula - contos, provérbios, cantos e adivinhas. Sua escrita funcionava como uma deportação total: "Eu expressava o que eu não era. Eu percebia do mundo uma construçâo ocidental, desabitada, e ela me parecia ser a única que valia" ${ }^{30}$.

"Somos o que comemos. Também somos as histórias em quadrinhos que consumimos na infância”, diz Carlos Fuentes em seu livro de ensaios Eu e os Outros - Ensaios Escolhidos ${ }^{31}$. Nessa obra, o romancista e crítico literário mexicano também comenta suas primeiras experiências como leitor e escritor. Fuentes passou boa parte de sua infância dividido entre dois mundos: ao sul, o México e uma história de derrotas; ao norte, a autoconfiança dos Estados Unidos e a celebração de inúmeras vitórias. Longe de sua terra natal, seu imaginário sobre o México era paulatinamente concebido por meio das palavras de seu pai: "um país inexistente, eu acreditava então, inventado por meu pai para alimentar minha imaginação infantil com mais uma ficção maravilhosa" ${ }^{2}$. Assim como Chamoiseau, Fuentes embarca numa viagem literária e histórica rememorando leituras e escritas de sua infância e juventude: "Eu escrevia com urgência porque minha ausência se tornara um destino, embora fosse um destino comum: comum ao meu próprio corpo de jovem, ao velho corpo do meu país, e ao corpo problemático e insone da minha língua"33.

Ainda adolescente, Chamoiseau conhece a poesia doudouista, cuja escrita reproduzia o olhar dos antigos cronistas ao exaltar a beleza das paisagens da ilha, o branco da areia, o azul do céu. Ávida pela aquisição da cultura letrada francesa, a intelligentsia mulata que entâo se formava em pleno regime colonial expressava poeticamente uma visão exótica da realidade crioula e por isso exteriorizada e superficial.

Só restava como soluçáo a estes escritores os exemplos do Centro dominador que os aspirava. Eles se entregavam a estes Centros com beatitude ou carregados de falsas armas de uma contestaçáo mimética. Eu lia entáo seus graciosos textos e me

30 Idem, Ibidem, p. 47.

31 FUENTES, Carlos. Eu e os Outros: Ensaios Escolhidos. Trad. de Sergio Flaksman. Rio de Janeiro: Rocco, 1989. p. 12

32 Idem, Ibidem, p. 13.

33 Idem, Ibidem, p. 29. 
emocionava ao encontrar um pouco de mim mesmo, como uma sombra do país-meu que esses escritores tinham colocado nos paióis de uma cidadela estrangeira. Cidadela que os livros divinizados tinham erguido neles, tinham plantado em $\mathrm{mim}^{34}$.

O escritor se dá conta, então, de que essas leituras o haviam distanciado ainda mais de seu país, pois sua escrita se expressava de maneira também exteriorizada, bem como seus personagens e os locais das açóes que nada representavam ou se assemelhavam aos personagens dos contos e histórias crioulas. "E essas forças me foram impostas com a autoridade imperiosa de seu mundo que apagava o meu" 35 .

$\mathrm{O}$ escritor-personagem tem plena consciência de que a dominação, refletida e por isso realizada através do universo literário, se faz nos moldes imperiais de conquista: "De quais hipnoses era eu vítima à maneira desses poetas-doudous que, em plena escravidão, só viram no seu entorno a medida paradisíaca?" "36. Vale ressaltar que na época das grandes navegaçóes, cuja produção escrita serviu de fonte de inspiração aos poetas-doudous, o mito do paraíso perdido associado ao interesse dos governos pela expansão do território por vias da colonização impulsionou um grande número de aventureiros, marinheiros, piratas e missionários a partir em busca de promessas de riqueza e felicidade e de contato pleno com a natureza em terras de além-mar. Não é de se espantar, portanto, que ao avistarem os primeiros sinais de terra, acreditassem estar diante do tão almejado paraíso, idealização que revela, segundo Nuñez, "uma ânsia europeia de superar sua própria realidade e forjar um mundo ideal na realidade distante, talvez uma espécie de refúgio contra suas próprias misérias e restriçóes" ${ }^{37}$. Isso contribui para que os primeiros registros de viajantes fossem impregnados de um imaginário povoado pelo mito do bom selvagem e da natureza ainda intocada, pela fascinação que exerciam o exótico e o primitivo.

Os poetas doudous, apesar de verem a ilha com o olhar de antigos viajan-

${ }^{34}$ CHAMOISEAU, Patrick. Écrire en Pays Dominé. Paris: Gallimard, 1997. p. 54.

35 Idem, Ibidem.

${ }^{36}$ Idem, Ibidem, p. 258.

37 NÚNEZZ, Estuardo. "O Elemento Latino-Americano em Outras Literaturas". In: América Latina em sua Literatura. Trad. de Luiz João Gaio. São Paulo: Perspectiva, 1972, p. 86. 
tes e exaltá-la em seus escritos, acabam por reconstituir um pouco do que seria a cultura crioula, muito embora estivessem sempre comprometidos em aproximar o máximo de sua expressão artística ao que era produzido na França.

Esses autores estavam, apesar de tudo, próximos de uma realidade crioula bem mais vivaz e palpitante do que hoje em dia. Apesar de ignorá-la, aflorá-la, ela aí estava, ela os banhava, e por trás de suas palavras, ao lado de suas imagens, em negativo às suas intençôes, com seus silêncios e com o que eles sussurravam, podemos reconstituir pulsaçóes inteiras da cultura crioula, esta cultura que hoje é cheia de imobilidades e que se deve reativar ${ }^{38}$.

A literatura ocidental, quando lida e estudada em uma comunidade que sofre a violência de um esvaziamento cultural em prol de um assimilacionismo alienante, ajuda a criar uma mentalidade mimética e por isso uma produção criativa forjada sob os ideais metropolitanos. Grande parte da produção literária da Martinica foi realizada sob o fascínio do Centro Francês, como se o escritor e seu público leitor lá estivessem, e assim totalmente dissociada da terra.

quando o modo-de-ser, o modo-de-pensar, o modo-de-se-pensar, o modo-de-pensar-seu-pensamento, o modo-de-consumir, o modo-de-se-distrair, o modo-de-se-cuidar, o modo-de-se-emocionar... - se viam assim importados, não era concebível nenhum brilho criador..."39

A constatação que faz Chamoiseau em relação ao bloqueio de sua escrita torna-se para ele ainda mais evidente quando descobre a Negritude, movimento literário anunciado no período entre guerras e que tem como figura principal, nas Antilhas, o poeta martinicano Aimé Césaire. Como alternativa de resistência ao colonialismo, a Negritude contesta a visão negativa em rela-

38 CHAMOISEAU, Patrick \& CONFIANT, Raphaël. Lettres Créoles. Paris: Gallimard, 1999. p. 122.

39 Idem, Ibidem. 
ção à África e restaura a dimensão africana da população americana e caribenha, o que representaria, assim, o desejo de volta à terra de origem.

Em Le Discours Antillais, Glissant considera ser o Retorno, a primeira pulsão de uma população arrancada de sua terra natal; no entanto, esse desejo é enfraquecido na medida em que as lembranças da terra de origem se tornam a cada dia mais obscurecidas e gradativamente substituídas - no caso de uma populaçáo dominada como a da Martinica - por uma pulsão mimética.

A pulsão mimética é uma violência insidiosa. Um povo que é a ela submetido leva muito tempo para conceber de maneira coletiva e crítica o seu peso, mas suporta de imediato o traumatismo. Na Martinica, onde a população transbordada constituiu-se em povo, sem poder assumir a terra de modo efetivo, a comunidade tentou exorcizar o Retorno impossível através do que eu chamo uma prática do Desvio. ${ }^{40}$

O Desvio de que trata Glissant é o recurso usado por uma população que luta contra um inimigo invisível - a "Dominação Silenciosa", explicitada em Écrire en Pays Dominé. O Desvio é, então, a necessidade de se buscar fora de seu espaço armas para escapar à dominação. A Negritude de Césaire, segundo Glissant, foi uma forma de Desvio, pois foi uma poética que encontrou na África "a solução possível do insolúvel a resoluçóes praticadas por outros povos" ${ }^{41}$. Contudo, essa prática só seria proveitosa se a volta ao real antilhano fosse feita de uma nova maneira, "deve-se voltar ao lugar. O Desvio só é uma astúcia proveitosa se o Retorno é fecundo [...] retorno ao ponto de intricamento, de onde foi-se desviado por força”"42.

Embora a Negritude se inscreva profundamente no campo referencial antilhano, ao celebrar os valores de um mundo negro, acaba por ignorar a infinidade de traços indígenas, europeus e asiáticos que também faziam parte da constituição cultural martinicana.

Embevecido e influenciado pela poesia de Césaire, Chamoiseau escreve

${ }_{40}$ GLISSANT, Édouard. Le Discours Antillais. Paris: Gallimard, 1997. p. 47.

41 Idem, Ibidem.

42 Idem, Ibidem, p. 56-57. 
peças de teatro contra o colonialismo e em favor de uma essência negra não conseguindo, entretanto, desvencilhar-se de um impasse: produzia textos que nada lhe sugeriam para desvendar o real antilhano e as denúncias às violências coloniais, ao modo de Césaire, eram invalidadas pelo desenvolvimento socioeconômico da ilha, devido à lei da departamentalização de 1946.

Eu perdi um pouco a febre da escrita. Eu habitava incertezas torpes. Reclamar contra o quê? A liberdade não era este crescimento aparente? O que desejar ainda? Alguns 'pequenos' povos não poderiam desabrochar com estas economias de transferência e de abundâncias consumistas? Não seria preferível se deixar levar pelo 'Desenvolvimento' e avançar rumo à soberania? Não éramos nós mais bem servidos do que estas independências esfarrapadas do Caribe? O essencial não era escapar à indignidade do ventre vazio? ${ }^{43}$

No artigo "Negritude, Negrismo, Literaturas de Afro-Descendentes", as autoras lembram que embora tenha havido críticas em relação à Negritude, pelo seu essencialismo ou epidermização, o movimento foi de extrema importância para uma nova percepção do negro na sociedade, pois "representou o primeiro momento de luta contra a alienação engendrada pelo sistema colonialista, escravocrata, participando da relação dialética branco/negro, e preencheu o primeiro espaço de conscientização do negro" ${ }^{4}$.

Contudo, esta tentativa de se buscar as origens nas raízes africanas como ruptura com a identidade de colonizado é logo substituída pelo ideal da cidadania francesa, a qual torna possível, mesmo que ilusoriamente, obter as mesmas vantagens de um cidadão metropolitano. Esse desejo de tornar-se francês, branco e, portanto, socialmente aceito, já vinha sendo despertado desde meados do século XIX, tornando-se "realizável" com a medida proclamada em 25 de fevereiro de 1848 pela Segunda República, o decreto de abolição da escravatura. Teoricamente, esse decreto permite aos novos cidadãos, quase $60 \%$

43 CHAMOISEAU, Patrick. Écrire en Pays Dominé. Paris: Gallimard, 1997. p. 83. Grifos do autor.

${ }^{44}$ FIGUEIREDO et al. "Negritude, Negrismo, Literaturas de Afro-Descendentes". (In): FIGUEIREDO, E. Conceitos de Literatura e Cultura. Juiz de Fora: UFJF, 2005, p. 322-323. 
da população da Martinica, a igualdade política e social, a cidadania plena, o direito ao voto e a um trabalho remunerado, a educação e o acesso à terra. Um século se passou até chegarmos à lei de 1946, durante todo esse período, a ideia de cidadania e o desejo de embranquecimento moldaram o imaginário da população martinicana.

A República extinguia teoricamente todas as diferenças entre os cidadáos. Ela apagava a história servil enquanto o passado desigual continuava nas práticas cotidianas e mentais nas Colônias e na Metrópole. O esquecimento da escravidão tornava-se, entretanto, a mola desta nova cidadania sem que a experiência da escravidão que impregnava as vidas pudesse desaparecer da lembrança ${ }^{45}$.

Glissant considera a colonização francesa na Martinica como uma das mais bem sucedidas da história moderna, ou seja, foi a que conseguiu despersonificar completamente toda uma comunidade e ainda fez com que essa mesma comunidade absorvesse um sistema de identificação ao modelo francês como única garantia de obter um estatuto social.

[...] o traumatismo do desenraizamento matriz original (a África) ainda intervém em surdina. O sonho de retorno à África, que marcou as duas primeiras geraçóes importadas, certamente desapareceu da consciência coletiva, mas foi substituído na história sofrida pelo mito da cidadania francesa: este mito contraria o enraizamento harmonioso ou não do homem martinicano em sua terra ${ }^{46}$.

Chamoiseau, em pleno impasse, desabafa: "O que nós opúnhamos aos antigos colonialistas flutuava dali em diante em um formol de valores sedutores que nos anestesiavam. Não mais inimigos aparentes. Só uma autodecom-

45 CONSTANT, Fred \& DANIEL, Justin. 1946 - 1996. Cinquante Ans de Départamentalisation Outre-mer. Paris: L'Harmattan, 1997. p. 294.

46 GLISSANT, Édouard. Le Discours Antillais. Paris: Gallimard, 1997. p. 148-149. 
posição. Eu não entendia o que se passava conosco" ${ }^{47}$.

Distante há quase dez anos da Martinica em razão de estudos universitários na França, o escritor se vê forçado a buscar algo que o identifique diante do que declara ser a "estranheza francesa".

A estranheza francesa (suas estaçóes, suas neves, seus ritmos suburbanos, seus transportes subterrâneos de cem mil solidôes) me remetia quase nu a mim mesmo. Distante do conforto natal, somos forçados a dar nome a nós mesmos, a nos nomearmos diante dos outros [...] eu vivia na antecipação de uma volta regeneradora... Uma maré de país-natal inundava minha memória ${ }^{48}$.

Será de fato a constataçáo de que sua escrita pouco tratava dele mesmo ou de seu país que a releitura dos romances Malemort de Édouard Glissant e Dézafi do haitiano Frankétienne entram para construir as bases de um mergulho nas profundezas deste "Nós" a descobrir. Chamoiseau percebe nesses dois textos um trabalho linguístico, temático e estrutural que evidencia uma penetração no real antilhano, convidando-o a um ponto de partida que funde e fundamente sua escrita literária e que dê conta de um (re)conhecimento do passado: "Reler tudo. Reexplorar tudo. Reinterrogar tudo. Era preciso tentar a urgência interior do olhar novo, o que associa os contrários, domestica os paradoxos e frequenta o impossível sem algum dogma" ${ }^{49}$.

Absorto e inspirado por essas duas obras, Chamoiseau mergulha na cultura crioula e escreve, nessa época, dois grandes romances que póem em prática a estética da oralidade ${ }^{50}$ : Chroniques des Sept Misères ${ }^{51}$ em 1986 e Solibo Magnifi$q u e^{52}$ em 1988. Em ambos, o autor revela, através da escrita, a oralidade crioula, porém problematizando essa passagem. Em Solibo Magnifique, o narrador

47 CHAMOISEAU, Patrick. Écrire en Pays Dominé. Paris: Gallimard, 1997. p. 77.

48 Idem, Ibidem.

49 Idem, Ibidem, p. 103.

50 Ver estudo de WELLS, Catherine. L'Oraliture dans Solibo Magnifique de Patrick Chamoiseau. Québec: GRELCA, 1994.

51 CHAMOISEAU, Patrick. Chronique des Sept Misères. Paris: Gallimard, 1986.

52 Idem. Solibo Magnifique. Paris: Gallimard, 1988. 
declara: "Como escrever a palavra de Solibo? Relendo minhas primeiras notas do tempo em que eu o seguia na feira, eu entendi que escrever o oral era uma traição, perdiam-se as entonações, as mímicas, o gestual do contador" ${ }^{53}$. Já em Chroniques des Sept Misères, o autor sugere que o esvaziamento da cultura oral crioula se dá pela explosão do consumo em massa que acarreta o desaparecimento dos feirantes e trabalhadores de rua, os chamados djobeurs.

\section{A rede textual}

A partir de suas primeiras produçôes romanescas, Chamoiseau começa a mostrar o embriáo de um novo projeto literário. O escritor evidencia que, para escrever em país dominado, é preciso recuperar o "já escrito", o "já dito", fundamentando a importância da memória de leituras, ou seja, dessa rede emaranhada de textos que compóem uma sentimenthèque. Para ele, a literatura crioula "coloca como princípio que não existe nada em nosso mundo que seja pequeno, pobre, inútil, vulgar, inapto a enriquecer um projeto literário" ${ }^{54}$.

A visão interior evocada pelos signatários do Éloge de la Créolité é a mesma que caracteriza a viagem memorial do escritor em Écrire en Pays Dominé. Ao retomar suas leituras, ele lança sobre elas um novo olhar, desembaraçando-se da visão exteriorizada operada pelo filtro francês e alcançando uma projeção no íntimo de sua realidade. Podemos, assim, aproximar o procedimento literário de Chamoiseau ao princípio da obra de Jorge Luis Borges. O escritor argentino retoma a ideia da narrativa como constituída a partir de várias outras narrativas, é a memória individual - de sua própria biblioteca ou sentimenthèque -, que revisita e reinterpreta o coletivo. Pinto salienta que os relatos borgeanos "refazem a trajetória de engendramento de muitas histórias - sempre no plural e na determinação do diverso - e indicam a importância não apenas do resultado final, do conteúdo conjectural de uma narração, mas sim de seu engenho, do trabalho em si de tessitura da narrativa literária" ${ }^{5}$. Esse "trabalho em si de tessitura da narrativa literária” de que fala Pinto, é justamente o que faz o escritor em Écrire en Pays Dominé quando diz precisar dos sinais de toda

53 Idem, Ibidem.

54 Idem, Ibidem, p. 39.

55 PINTO, Júlio Pimentel. Uma Memória do Mundo: Ficção, Memória e História em Jorge Luis Borges. São Paulo: Estação Liberdade: FAPESP, 1998. p. 167. 
uma gama desordenada de "livros amados", de "autores amados" para, enfim, iniciar sua própria escrita.

Embora longo, o trecho que segue ilustra bem a importância que Chamoiseau concede à releitura literária e esclarece porque a primeira parte do romance é intitulada Anagogie par les livres endormis: Où l'enfant qui lisait va devoir tout relire...

O grande livro pode adormecer, e ele adormece frequentemente, pois ele escapa às épocas, às urgências alienantes de uma situação, às cegueiras de uma dor particular. Ele não é de nenhuma idade ou nenhuma história; do tempo de sua concepção, do país de sua aparição, encontramos somente algumas escamas que enraízam o vigor de seu ser. Mas, flexível, aberto, rico em ambiguidade transversal, acaba por ressoar nas urgências, nas feridas, nas idades, nas histórias. Mas, mesmo que ele ajude a sobreviver no coração destas tormentas, não é certo confundir uma ressonância particular com a sinfonia geral de um verdadeiro despertar. Suas camadas de sombras são numerosas, e cada uma, em suas ambiguidades, leva o germe de mil despertares possíveis ${ }^{56}$.

Ao usar metaforicamente "o adormecer e o despertar de um livro" para indicar a possibilidade oferecida por uma obra literária de garantir inúmeras outras leituras, conseguimos entender a escolha do autor pelo termo "anagogia” contido no título do primeiro capítulo. Segundo o Novo Dicionário Aurélio da Lingua Portuguesa, o substantivo origina-se do grego anagogé e significa a "elevação da alma na contemplação das coisas divinas; êxtase, arrebatamento, enlevo" 57 . É como se o escritor necessitasse ser impulsionado e envolvido por um maravilhamento inicial para conseguir libertar seu imaginário.

Para que a escrita seja uma ferramenta de combate ao domínio e que

56 CHAMOISEAU, Patrick. Écrire en Pays Dominé. Paris: Gallimard, 1997. p. 30-31.

57 FERREIRA, Aurélio B. de Hollanda. Novo Dicionário Aurélio da Língua Portuguesa. 2. ed. Rio de Janeiro: Nova Fronteira, 1986. p. 112. 
opere a caminho de uma nova poética, é preciso "construir as histórias no desejo-imaginativo de todas as histórias possíveis" ${ }^{28}$, de modo que, ao entender todos os elementos culturais equivalentes em valor, um passo seja dado dentro de uma poética que, como deseja Glissant, seja uma maneira de "se conceber, de conceber sua relação consigo mesmo e com o outro e de exprimi-la" 59 .

Esse passado esfacelado e obscuro, cuja cadeia de acontecimentos parte de uma historiografia que se quer linear e homogênea, vai aos poucos reacendendo no presente à medida que a história é recontada através e pela ficção. Admitindo-se, conforme Beatriz Sarlo, que toda a narração do passado é vicária, "pois implica sujeitos que procuram entender alguma coisa colocando-se, pela imaginação ou pelo conhecimento, no lugar dos que a viveram de fato" 60 , o papel do escritor em Écrire en Pays Dominé é o de desconstruir o emaranhado discursivo de um sistema de representaçáo cultural criado pelo Ocidente, reinventando, através da literatura, um imaginário que considere de mesmo valor todos os elementos culturais presentes. O escritor é aquele que, segundo Walter Benjamin, não distingue os grandes dos pequenos acontecimentos e que "leva em conta a verdade de que nada do que um dia aconteceu pode ser considerado perdido para a história" ${ }^{1}$.

Cabe destacar que embora o tema da origem não esteja explicitado, está fortemente relacionado ao desassossego inicial do escritor e sugerido de forma camuflada no decorrer de sua anagogia, visto que se por um momento Chamoiseau resgata seus precursores - na tentativa de traçar uma linhagem para si -, por outro, sob o ponto de vista coletivo, reconstrói cronologicamente a história literária martinicana. Contudo, a escolha por uma sentimenthèque como recurso ficcional para revisitar a experiência de leitura do personagem desfaz por si só a ideia preconcebida de uma origem clara e definida. Em primeiro lugar, por tratar-se de fragmentos de memória, de possíveis invençôes sobre aquilo que leu ou achou ter lido; em segundo, porque o próprio personagem, ao modo de Borges, considera a escrita como fruto de várias outras escritas,

58 CHAMOISEAU, Patrick. Écrire en Pays Dominé. Paris: Gallimard, 1997. p. 317.

59 GLISSANT, Édouard. Introduction à une Poétique du Divers. Paris: Gallimard, 1996. p. 135.

60 SARLO, Beatriz. Tempo passado: Cultura da Memória e Guinada Subjetiva. São Paulo: Companhia das Letras; Belo Horizonte: UFMG, 2007. p. 93.

61 BENJAMIN, Walter. Magia e Técnica, Arte e Politica. Obras Escolhidas I. Trad. de Sérgio Paulo Rouanet. São Paulo: Brasiliense, 1994. p. 223. 
um emaranhado textual cuja noção de autoria ou origem é, por isso, abalada. Começa a se configurar, portanto, uma proposta poética engendrada e dispersa em uma malha literária rizomática, algo que chama o imaginário, que se quer nascido das incertezas e indefinições.

\section{PATRICK CHAMOISEAU ET LA RELECTURE DE L'IMAGINAIRE EN PAYS DOMINÉ}

RÉSUMÉ

Ce texte présente le premier chapitre de l'œuvre Écrire en Pays Dominé, de Patrick Chamoiseau, afin de reconnaittre l'existence d'une domination qui se réalise silencieusement dans l'imaginaire collectif martiniquais, et de rechercher le rôle de la (re)lecture d'œuvres littéraires comme outil de résistance à ce contrôle.

MOTS-CLÉS: domination, écrit, lecture.

Recebido em: 26/03/12

Aprovado em: 20/11/12 